Рад примљен: 15. 6. 2019.

Рад прихваћен: 27. 8. 2019.

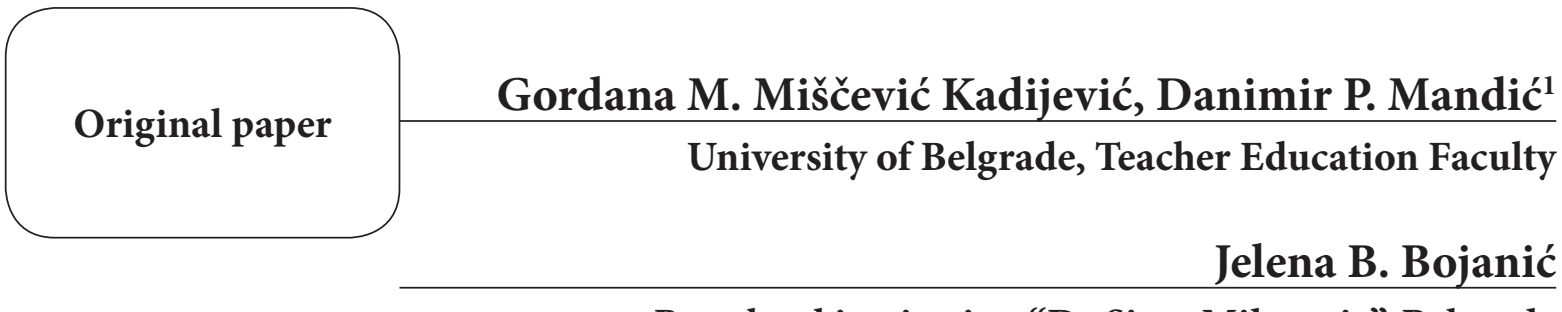 \\ Preschool institution “Dr Sima Milosevic”, Belgrade
}

\section{Preschool Teachers' Assessment of the Integrative Approach to Environmental Education ${ }^{2}$}

\begin{abstract}
Summary: An integrated educational activity in preschool context is a system whereby the components from various subject areas operate as a single unit. This paper examines the results of the research on the impact of preschool teachers' professional experience on their assessment of the need for the integration of the Environmental Education content with the contents of other subject areas at preschool level. The sample consisted of 148 respondents: 73 pre-service preschool teachers and 75 in-service preschool teachers. It was found that in-service preschool teachers have a more positive assessment of the need for this integration than pre-service preschool teachers. In addition, there was no correlation between the in-service teachers' duration of service and their assessment of this need. Possible reasons for such findings are given in the paper. Effective integrated activities using the contents of two or more subject areas may be developed through systematic observations of the practical work of in-service preschool teachers and children in their groups. Suggestions for further research are included in the paper as well.
\end{abstract}

Keywords: Environmental Education, in-service preschool teachers, integrative approach, preschool children, pre-service preschool teachers.

\footnotetext{
1 danimir.mandic@uf.bg.ac.rs

2 This research is part of the research project "Concepts and strategies for ensuring the quality of basic education", no. 179020, whose implementation has been funded by the Ministry of Education, Science, and Technological Development of the Republic of Serbia (2011-2019).

Copyright ( 2019 by the authors, licensee Teacher Education Faculty University of Belgrade, SERBIA.

This is an open access article distributed under the terms of the Creative Commons Attribution License (CC BY 4.0) (https://creativecommons.org/licenses/by/4.0/) which permits unrestricted use, distribution, and reproduction in any medium, provided the original paper is accurately cited.
} 


\section{Introduction}

Preschool children perceive the world around them as a whole, not as a composition of isolated elements. Contemporary kindergarten education curriculum frameworks aim at promoting holistic learning (Bautista, Múñez, Bull, 2016). Some ideas from the theories of Jean Piaget, Lev Vygotsky, John Dewey, or Jerome Bruner support an integrated approach in the work with preschoolers. The historical development of an integrative teaching approach shows that researchers in the past dealt mainly with schools and teaching (e.g., Andevski, 2016 and Stanišić, 2016 in the field of environmental education; Pribićević et al., 2017 in the interactive, computer-assisted biology teaching) and much less with the specific integration of subject areas in preschools. Most articles are based on a theoretical review of the integrated approach benefits, rather than a concrete measurable integration benefits when, for example, two subject areas are integrated. In the modern approach to learning and child development the recommendation is that preschool children do not learn about different scientific areas as they do later in the school context because learning within separate domains at preschool age can lead to building up isolated skills and fragmented knowledge.

An educational approach that is not suitable for a specific stage may have a negative impact on children (Başkale et al., 2009) and, sometimes, preschool teachers are not skillful enough despite feeling competent to design and use different learning centers (Metin, 2017). The thematic approach, which integrates knowledge from different subject areas, is perceived to be more suitable for the development of knowledge and skills in the early childhood education. Moreover, pedagogical goals lie within the context activity goals, working goals, and trans-disciplinary goals (Björklund, Ahlskog-Björkman, 2017, 2018). For young children, learning takes place all the time and all around, and they can learn best when subject areas are interconnected (Yu et al., 2018; Moomaw, Davis, 2010). Despite the fact that the work in the preschool period should not be subject-orientated, some basic content of mathematics, science, culture etc., must be there (Samuelsson, Carlsson, 2008). Integration is a very important issue at all levels of education. There is a need for an integration of teacher-training programs into the whole system, which includes school subjects, teaching practice, and experience in schools-workshops. The discussion about students' values, understanding children's nature, and the objectives of education in modern theories of education, results in a need for a better insight into some basic pedagogical issues (Tadić, Maksimović, Mrvoš, 2016). There is an interesting intention in the literature to create an integrated curriculum designed for pre-service preschool teachers. It describes a three-year pilot program which contains the integration of visual art, speech development, and the use of computers (Toren, Maiselman, Inbar, 2008). The researchers tried to identify the preschool teachers' beliefs about the integration of visual arts with other activities $(\mathrm{Oz}-$ turk, Erden, 2011). Computers have been seen as important tools in presenting various subject (discipline-specific) contents, in particular in the field of art and language culture. When it comes to the integration of different subject areas, researchers and kindergarten teachers attempted to integrate different subjects into the music curriculum through movement and games, thus encouraging children's creativity (Lau, Grieshaber, 2018), teach mathematics and art in thematic sessions (Björklund, Ahlskog-Björkman, 2017), integrate science and art (Perkins, Stoycheva, 2016), or preschool mathematics and physical education (Malinović-Jovanović, Ristić, 2018). Neuman (2014) described the values of multidisciplinary projects in which preschoolers learned about the sound through listening, fine art activities, and writing. A picture story reading method was successfully associated with young children learning about magnetism (Kalogiannakis, Nirgianaki, Papadakis, 2018). The contents of En- 
vironmental Education seem very familiar to preschool children, because this is something that surrounds them and which they see and experience every day. Therefore, it is very important to methodologically design activities familiar to children and integrated within different subject areas (fields). The importance of integration is actually reflected in: its contribution to developing basic skills and a better understanding of the specific content; the consideration of certain problems from different aspects; and developing children's habits to view natural phenomena, processes, and relationships in their environment more completely as a unified system of interrelated and inter-dependent elements. One way to develop an interest in discovering something new and unknown is in its connection with something familiar and interesting.

In Serbian context, preschool education refers to the care and education of children from six months old to primary school age, which starts between 6,5 and 7,5 years of age. Preschool teachers work with children who are approximately three to seven years old. Higher education for preschool teachers lasts 4 years, with the possibility of enrolling at a one-year Master's Degree Course. Pre-service preschool teachers are encouraged to practice planning, implementation, and evaluation of work in kindergartens. They cooperate, methodologically adjust content as part of children's activities, and encourage different aspects of child development. The contents from different subject areas (fields) should be logically linked and complement each other in order to support and promote the child's development and competencies. The integrative approach of the pre-service preschool teachers involves creating meaningful connections between similar aspects in different subject areas (disciplines). Although it may contain some of the elements that belong to the individual, discipline-specific contents (physics, biology, chemistry, geography), Environmental Education generally has an integrative character.

\section{Problem and research aim}

The research about the environmental content integration with other subject areas in preschool education is very rare; it has primarily examined the benefits of integrated approaches, such as the values of multidisciplinary projects (Neuman, 2014), or encouraging children's creativity (Lau, Grieshaber, 2018). Empirical examinations regarding different aspects of integrated approach, such as the need for providing it, have been missing from the authors' reading. To fill this gap, this study examined the teachers' assessments of the need for providing environmental education through content integration with other subject areas (fields) present in preschools. The main aim was to examine the influence of the professional experience of the in-service preschool teachers on their assessment of the need for an integrated environmental education.

\section{Research tasks}

1. Study the influence of professional experience on assessment of the need for the integration of environmental education content with other subject areas in kindergarten. More precisely, investigate potential differences between pre-service and in-service preschool teachers in their assessment of the need for this integration.

2. Examine the correlation between the professional experience of in-service preschool teachers and their assessment of the need for the integration.

3. Discover subject content, if any, within which the integration in question could mostly be realized.

\section{Research hypotheses}

1. Pre-service preschool teachers and in-service preschool teachers do not differ in their assessment of the need for the integration of environmental education content with contents from other subject areas (fields) at preschool institutions. 
2. There is no correlation between the professional experience of the in-service preschool teachers and their assessment of the need for the integrated environmental education.

3. All respondents assess that environmental education content could be equally integrated with contents from other subject areas (fields) in preschool.

\section{Method}

\section{Research sample}

This study used a sample of 148 respondents: 73 pre-service preschool teachers from the preschool department of the Teacher Education Faculty, University of Belgrade (Belgrade, Serbia), and 75 in-service preschool teachers from Belgrade preschools. The structure of the sample by age is given in Table 1, whereas the structure of the sample of in-service preschool teachers by professional experience is presented in Table 2.

Table 1. Sample structure by age.

\begin{tabular}{ccc}
\hline \multirow{2}{*}{ gge $^{1}$} & \multicolumn{2}{c}{ Frequency } \\
\cline { 2 - 3 } $20-29$ & 89 & $\%$ \\
$30-39$ & 46 & 60.1 \\
$40-49$ & 12 & 31.1 \\
$>49$ & 1 & 8.1 \\
In total & 148 & 0.7 \\
\hline
\end{tabular}

${ }^{1} \mathrm{M}=28.0, \mathrm{SD}=7.5$

The sample of respondents consisted primarily of younger persons: over $80 \%$ of all respondents were under the age of 35 . In the structure of the in-service preschool teachers' sample, over $70 \%$ of respondents had not more than 10 years of professional experience.
Table 2. In-service preschool teachers sample structure by professional experiencel

\begin{tabular}{ccc}
\hline $\begin{array}{c}\text { Professional experience } \\
\text { (in years) }\end{array}$ & \multicolumn{2}{c}{ Frequency } \\
\cline { 2 - 3 } & $f$ & $\%$ \\
\hline $1-5$ & 31 & 41.3 \\
$6-10$ & 23 & 30.7 \\
$11-15$ & 12 & 16.0 \\
$16-20$ & 7 & 9.3 \\
$>20$ & 2 & 2.7 \\
In total & 75 & 100 \\
\hline 1
\end{tabular}

\section{Research approach, instrument, and variables}

To examine respondents' assessment of the need for an integrative approach in the area of environmental education at preschool level, the study used descriptive-analytical method. The technique of scaling and a 5-point Likert-type scale were used for collecting the data. The scale comprised five statements regarding particular subject areas (e.g., "Environmental education could mostly be integrated within visual arts"). For each statement, the respondents indicated the extent to which they agree with it. To this end, a scale ranging from 1-strongly disagree to 5-strongly agree was used. The study used three variables: Teacher type (with values 1-pre-service and 2-in-service), Professional experience (denoting the duration of the respondent's professional experience in years of service), and Integration need. For individual subject areas, the last variable represented the assessment of the need for the integration in question expressed as a number 1-5. For all subject areas examined, this variable represented the average value of the responses regarding the five subject areas considered. Cronbach's alpha reliability of this measure was 0.86 for all 148 respondents and 0.89 for the in-service preschool teachers.

\section{Statistical analyses}

To test the first hypothesis, a $t$-test for independent samples was used. To test the second hypothesis, Pearson's correlations were determined. 
The last, third hypothesis was tested by using a $t$-test for paired samples.

\section{Results and Discussion}

The first research task was to investigate potential differences between the pre-service and in-service preschool teachers in their assessment of the need for the integration of environmental education content with other subject areas in kindergarten. Given the fact that we examined differences in the average values for two groups of preschool teachers (pre-service $v s$. inservice), a $t$-test for independent samples was used. The results of the $t$-test applied are summarized in Table 3. The results indicate that the in-service preschool teachers had a more positive assessment of the need for the integration in question than their less experienced colleagues (pre-service preschool teachers), which enabled us to reject the first research hypothesis that such a difference is not present.

Why was this difference present? At the Teacher Education Faculty, pre-service preschool teachers learn about content integration within individual methodology-different faculty subjects. Within the faculty subject Environmental education methodology, students learn about goals, tasks, methods of work with children, work forms, educational tools, and all forms through which content could be linked to contents from other subject areas, in order to promote and support the child's harmonious development. The goal of this subject is to prepare future preschool teachers to help children of age 3-7 to establish an active contact with different aspects in the world around them, to enrich their way of un- derstanding the world, and to develop research activities. While doing practical work with children, pre-service preschool teachers do not teach the content from each methodology-related faculty course isolated from other subjects. In other words, their work with children is not directed towards one subject area only, such as developing speech, exploring the environment, or appreciating music. Instead, task instructions are based on the idea of content integration in all activities, bearing in mind that children perceive the world around them as a whole, and therefore cannot learn the content that is separated and fragmented. However, being less experienced with implementing integrated activities in practice than in-service preschool teachers, they had a less positive assessment of the integration in question. That there was indeed the need for integrating the environmental education content with the contents of at least two subject areas at preschool level was evidenced by the fact that about $75 \%$ of the respondents choose "agree" or "strongly agree" when expressing their agreement with the statements regarding the need for the integration in question with contents from two or more subject areas. The difference in frequency found (66\% - pre-service teachers vs. $85 \%$ - in-service teachers; Chi-square $=7.705, d f$ $=1, p=0.006$ ) might also be attributed to an insufficient experience of the pre-service preschool teachers in implementing integrated activities.

The next research issue was related to the correlation (see the second research hypothesis). We focused on the correlation between the two variables: professional experience and the need for integration. Pearson's correlation was $-0.10(d f=73, p=0.409)$, meaning that these variables were not linearly correlated (Spear-

Table 3. Integration need by the type of preschool teacher.

\begin{tabular}{ccccc}
\hline $\begin{array}{c}\text { Teacher type } \\
\text { Variable }\end{array}$ & $\begin{array}{c}\text { Pre-service } \\
\mathrm{M} / \mathrm{SD} / n\end{array}$ & $\begin{array}{c}\text { In-service } \\
\mathrm{M} / \mathrm{SD} / n\end{array}$ & $\boldsymbol{t}$ & $\boldsymbol{d}$ \\
\hline Integration need & $3.18 / 0.80 / 73$ & $3.71 / 1.00 / 75$ & $-3.538^{1}$ & 146 \\
\hline${ }^{1} p<0.001$ & & & & \\
\end{tabular}


man's rho was also -0.10). In addition, they were not correlated under any of the commonly applied curve estimation models. The reason for the lack of the statistically significant relationship might be found in the fact that only $12 \%$ of the in-service preschool teachers had more than 15 years of professional experience, which possibly obscured the relationship in question due to a quite limited range of the data examined (Gravetter, Wallnau, 2009).

The last research issue was aimed at the subject area within which the integration in question could mostly be realized. The subject areas considered were Speech development, Visual Art, Mathematics, Physical Education, and Music Education. The average values of integration need were calculated for each subject area separately. Table 4 summarizes these values by teacher type.

Table 4. Need for integration by subject area and teacher type.

\begin{tabular}{lccc}
\hline $\begin{array}{c}\text { Teacher type } \\
\text { Subject area }\end{array}$ & All & $\begin{array}{c}\text { Pre- } \\
\text { service }\end{array}$ & In-service \\
\hline Visual art & 3.86 & 3.58 & 4.15 \\
Speech development & 3.69 & 3.36 & 4.01 \\
Mathematics & 3.33 & 2.97 & 3.68 \\
Physical education & 3.23 & 3.11 & 3.35 \\
Music education & 3.11 & 2.88 & 3.35 \\
\hline
\end{tabular}

The use of the $t$-test for paired samples showed that in each teacher sample, the average value of the integration need in Visual Art was higher than that in Mathematics, Physical Education, and Music education (all respondents: $p=0.000 v s . p=$ 0.066 for Visual Art - Speech development comparison; pre-service preschool teachers: $p<0.005 v s . p$ $=0.181$ for this comparison; in-service preschool teachers: $p=0.000 v s . p=0.191$ for the comparison). These results enabled us to reject the third research hypothesis and to conclude that it is the Visual Art with which the integration in question could mostly be realized. The integration of science and art was described in some previous research (Perkins, Stoycheva, 2016).

Visual Art may indeed have an important role in integrated activities. As mentioned earlier, there is an integrated program based on visual art, speech development, and the use of computers (Toren et al., 2008). Also, the connection between natural sciences and arts is described in terms of the collaboration between artists and scientists in order to create science inspired sculptures (Gurnon, Voss-Andreae, Stanley, 2013), for example. However, preschool teachers may tend not to integrate Visual Arts activities within other subjects (they may rather use them as a consolidation of other activities) as found in Ozturk and Erden (2011). Apart from Visual Art, the integration in question could also be realized within other subject areas, particularly with the Speech Development content. On the other hand, the attitudes towards this integration with Music Education indicate that it could be very rarely realized. These findings may be surprising, bearing in mind that some other studies focused on kindergarten teachers' attempts to integrate other subject areas into the music curriculum through movement and games (e.g., Lau \& Grieshaber, 2018).

\section{Conclusion}

This paper examined the assessment of the need for the integration of the Environmental Education content with the contents of other subject areas in preschools. It was found that, compared to the pre-service preschool teachers, the in-service preschool teachers had a more positive assessment of the need for this integration, possibly owing to their greater experience with implementing integrated activities on a day-to-day basis. Furthermore, there was no statistically significant correlation between the professional experience of the in-ser- 
vice preschool teachers and their assessment of this need, which might be the result of a quite limited range of the values of professional experience possibly obscuring the relationships in question. Further research may thus explore these relationships by using more diverse samples in terms of age, professional experience, and other factors of relevance. The respondents' answers revealed that Environmental Education content could mostly be practically realized in integration with the Visual Art content. Also, the integration in question could also be realized within other subject areas, especially with the Speech Development content. As already reported, the need for the integration of the Environmental Education content with the contents of at least two subject areas at preschool level was indicated by about three-fourths of the respondents. The integration of the Environmental Education content with the content of the Visual Art may be about drawing animals, plants, and factories, but this is really not a deep and substantial integration. It would be therefore important to identify the concrete practical elements about such integration by using the contents of two or more subject areas. To this end, bearing in mind their ample experience, the research may focus on the practical work of the in-service preschool teachers and children in their groups. As for the Environmental Education methodology course, it may be necessary to pay more attention not only to the benefits of integrating the contents, but also to a more detailed practical application of this approach during teaching practice of the pre-service preschool teachers in kindergartens, with a special emphasis on the selection of the contents of different subject areas to be integrated and the effective ways of integrating them.

\section{References}

- Andevski, M. (2016). Održivo ekološko obrazovanje - perspektiva za promenu kulture učenja. Inovacije u nastavi - časopis za savremenu nastavu, 29(4), 16-31. DOI: 10.5937/inovacije1604016A.

- Başkale, H.; Bahar, Z.; Başer, G.; Ari, M. (2009). Use of Piaget's theory in preschool nutrition education. Revista de Nutrição, 22, 905-917. DOI:10.1510/S1415-52732009000600012.

- Bautista, A.; Ng, S.-C.; Múñez, D.; Bull, R. (2016). Learning areas for holistic education: kindergarten teachers' curriculum priorities, professional development needs, and beliefs. International Journal of Child Care \& Education Policy, 10(1), 1-18, DOI: 10.1186/s40723-016-0024-4.

- Björklund, C; Ahlskog-Björkman, E. (2017). Approaches to teaching in thematic work: early childhood teachers' integration of mathematics and art. International Journal of Early Years Education, 25, 98-111, DO I:10.1080/09669760.2017.1287061.

- Björklund, C; Ahlskog-Björkman, E. (2018). From activity to transdisciplinarity and back again - preschool teachers' reasoning about pedagogical goals. International Journal of Early Years Education, 26, 90-103, DOI :10.1080/09669760.2017.1421524.

- Bustamante, A.; Greenfield, D.; Nayfeld, I. (2018). Early childhood science and engineering: engaging platforms for fostering domain-general learning skills. Education Sciences, 8(3), 144. DOI:10.3390/educsci8030144

- Gravetter, F. J.; Wallnau, L. B. (2009). Essentials of statistics for the behavioral sciences (8ed). Belmont, CA: Cengage Learning.

- Gurnon, D., Voss-Andreae, J., Stanley, J. (2013). Integrating art and science in undergraduate education. PloS Biology, 11, 1-4. 
- Kalogiannakis, M., Nirgianaki, G.M., \& Papadakis, S. (2018). Teaching Magnetism to Preschool Children: The Effectiveness of Picture Story Reading. Early Childhood Education Journal, 46, 535-546. DOI:10.1007/ s10643-017-0884-4.

- Lau, W., \& Grieshaber, S. (2018). School-based integrated curriculum: an integrated music approach in one Hong Kong kindergarten. British Journal of Music Education. 35, 133-152. DOI:10.1017/S0265051717000250.

- Malinović-Jovanović, N., \& Ristić, M. (2018). Possible models of integration of preschoolmathematics and physical education. Facta Universitatis Series: Physical Education and Sport, 16, 595-610.

- Metin, Ş. (2017). Investigation of the practices in learning centers of pre-school education institutes. Turkish Journal of Education, 6, 1-16. DOI: 10.19128/turje.267357.

- Moomaw, S., \& Davis, J. (2010). STEM comes to preschool. Young Children, 65, 12-14.

- Neuman, S. (2014). Content-rich instruction in preschool. Educational Leadership, 72, 36-40.

- Ozturk, E., \& Erden, F. (2011). Turkish preschool teachers' beliefs on integrated curriculum: integration of visual arts with other activities. Early Child Development and Care. 181, 891-907.

- Perkins, L.; Stoycheva, D. (2016). Preschoolers explore greenhouses by visiting a greenhouse, making a model, and growing plants. Journal of STEM Arts, Crafts, and Constructions, 1, 18-26.

- Pribićević, T., Miljanović, T., Odadžić,V., Mandić, D., \& Županec, V. (2017). The efficiency of interactive computer-assisted biology teaching in grammar schools. Croatian Journal of Education - Hrvatski časopis za odgoj i obrazovanje, 19(3), 803-839, DOI:10.15516/cje.v19i3.2677.

- Samuelsson, I., \& Carlsson, M. (2008). The playing learning child: towards a pedagogy of early childhood. Scandinavian Journal of Educational Research, 52, 623-641, DOI: 10.1080/00313830802497265.

- Stanišić, J. (2016). Karakteristike časova ekološkog obrazovanja u osnovnoj školi. Inovacije u nastavi-časopis za savremenu nastavu, 29(4), 87-100, DOI:10.5937/inovacije1604087S.

- Tadić, A., Maksimović, A., \& Mrvoš, I. (2016). The pedagogical concept of students of teacher education faculty [in Serbian: Vaspitni koncept studenata učiteljskog fakulteta]. Zbornik Instituta za pedagoška istraživanja. 48, 247-263, DOI: 10.2298/ZIPI1602247T.

- Toren, Z., Maiselman, D., \& Inbar, S. (2008). Curriculum integration: art, literature and technology in preservice kindergarten teacher training. Early Childhood Education Journal, 35, 327-333.

- Yu, Y., Shafto, P., Bonawitz, E., Yang, S., Golinkoff, R. M., Corriveau, K. Hirsh-Pasek, K. \& Xu, F. (2018). The theoretical and methodological opportunities afforded by guided play with young children. Frontiers in psychology, 9: 1152, DOI: 10.3389/fpsyg.2018.01152. 


\section{Гордана М. Мишчевић Кадијевић, Данимир П. Мандић}

Универзииетеи у Беоіраgу, Учитеиељски факулиеети

\section{Јелена Б. Бојанић}

Предиколска устианова „Др Сима Милочевић“, Беоірая

\section{ПРОЦЕНЕ ВАСПИТАЧА О ИНТЕГРАТИВНОМ ПРИСТУПУ УПОЗНАВАЬА ОКОЛИНЕ}

Детеие йреgиколскоі узрасий саїлеgава свети око себе као иелину и не дели іа на йојеgи-

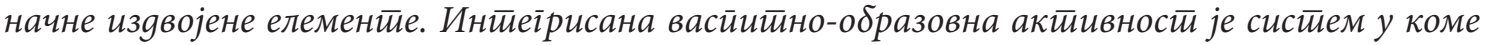
комйонениее из различитиих обласии йреgстиављају йоgсистеме који функиионишу као јеgинсиивена иелина. У савременим сазнањима о учеюу и развоју gеще йрейоручује се gа йреgиколска gеца не уче йо издвојеним научним областичма, како йо касније чине у иколском

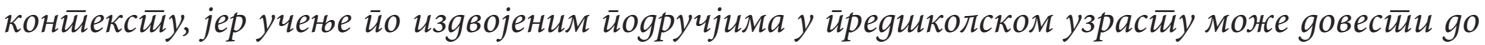
изірађиваюа изолованих вешитина. У овом раяу ирриказана је анализа исираживаюа уйииаја йрофесионалноі искусиива васиичйача на йрочену йойребе за иниееірачијом саяржаја из областии уйознаваюа околине са саяржајима из gруіих областии. Узорак се састиојао оg сиио

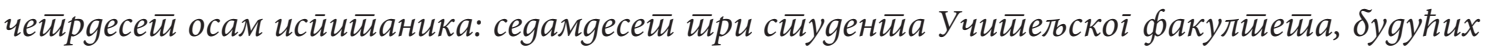
васиитйача, и сеgамgесей иетеи зайослених васиитичча. Цео узорак се иррвенстивено састиојао оg

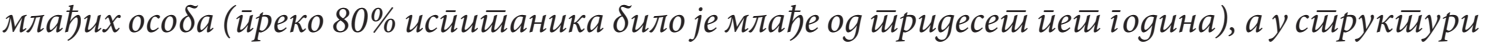
узорка зайослених васииитача ирреко 70\% исиитаника није имало више оg gесеті іолина йро-

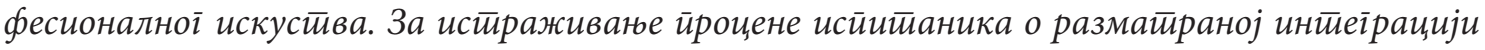

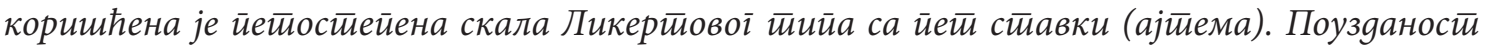
кориићене мере (Кронбах алфа) износила је 0.86. Истираживаюе је базирано на иессиирану слеgећих истираживачких хийоиеза: (1) ирри уйоређиваюу ирроцене буgућих и зайостених вас-

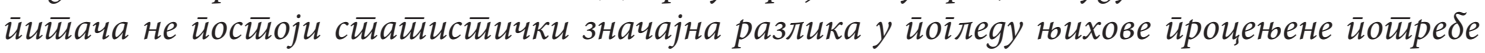

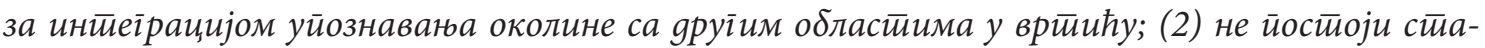

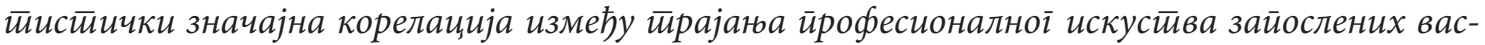

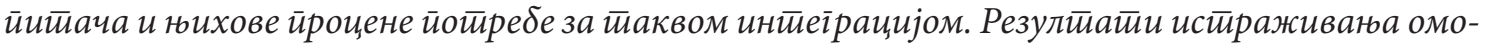
іућили су о ббациваюе само йрве хийоиеезе. Друіим речима, добијено је слеgеће: (1) У йоређеюь

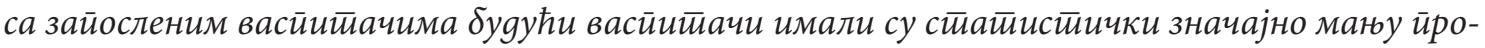

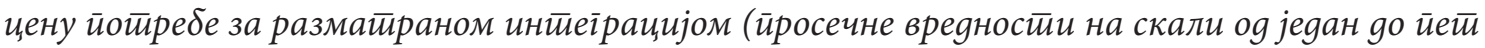

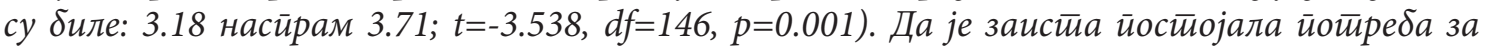
иниетераиијом саяржаја уйознавана околине са саяржајима из најмане gва обласиии, свеgочи

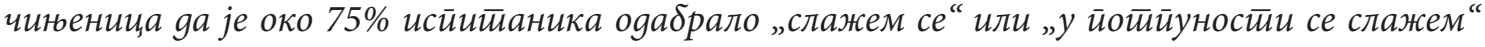

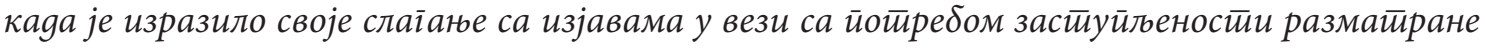

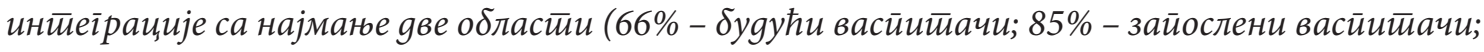

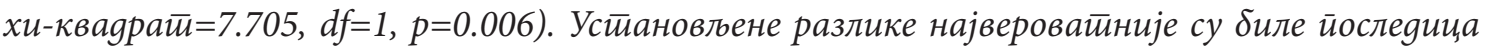

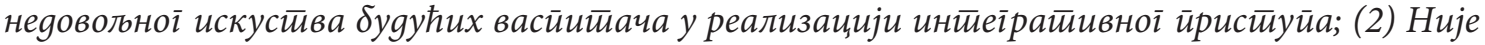

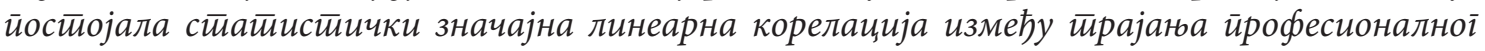

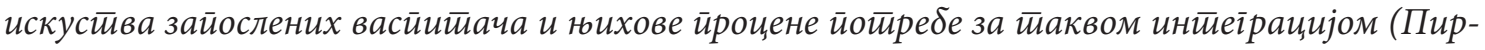


сонова корелација је била -0.10; Сйирманова корелација је тиакође била-0.10; $d f=73, p=0.409)$,

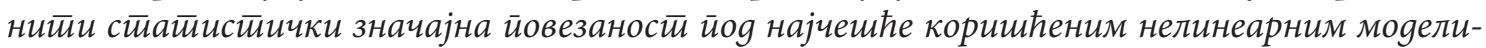

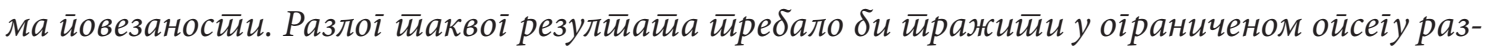

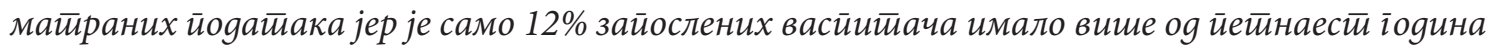

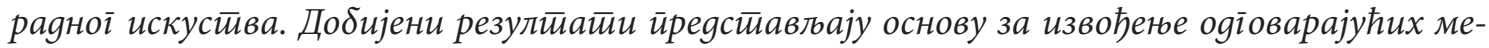

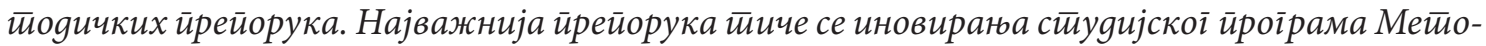

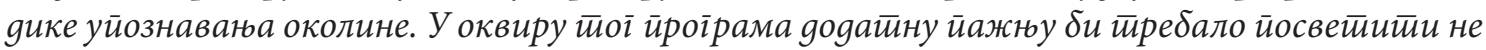

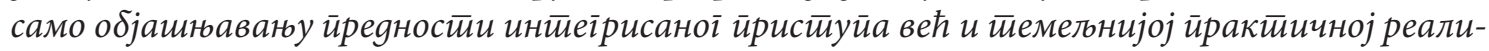

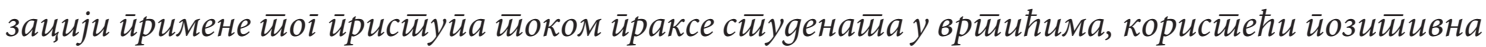

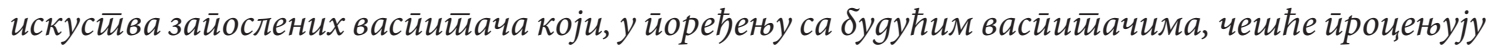

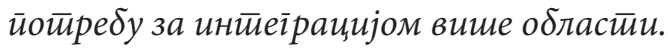

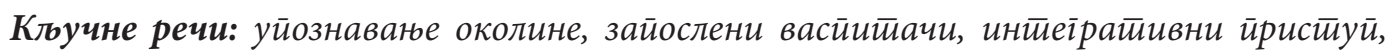

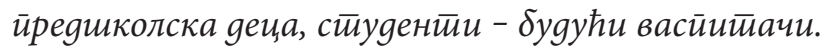

